\title{
Dampak Kualitas Air Tanah Terhadap Kualitas Melon (Cucumis Melo L.)
}

\section{The Impact of Ground Water Quality toward Melon Qulaity (Cucumis melo L.)}

\author{
Rini Setiawati \& Nurpilihan Bafdal \\ Program Studi Agroteknologi, Fakultas Teknologi Industri Pertanian Universitas Padjadjaran , \\ Indonesia
}

Diterima: 12-12-2019; Disetujui: 18-06-2020; Dipublish: 30-06-2020

*Coresponding Email: setiawatirini34@gmail.com

\begin{abstract}
Abstrak
Budidaya hidroponik tanaman melon dengan sistem fertigasi menggunakan air tanah merupakan salah satu teknologi budidaya yang diharapkan dapat meningkatkan mutu dan produksi hasil panen. Teknologi fertigasi (fertilizer dan irigasi) dengan menggunakan autopot yaitu sistem irigasi yang mampu memberikan air irigasi secara self watering system dengan tidak menggunakan tenaga listrik sehingga sistem fertigasi tersebut lebih efisien. Tujuan penelitian ini yaitu mengetahui pengaruh dampak kualitas air tanah terhadap kualitas tanaman melon (Cucumis melo L.). Metode penelitian yang digunakan yaitu metode deskriptif. Parameter kualitas buah melon yang digunakan pada penelitian ini yaitu kadar air, karbohidrat, protein, lemak, abu, vitamin C dan kemanisan (\% brix). Hasil penelitian mengenai kualitas air tanah menujukkan jika kualitas air tanah yang digunakan termasuk kedalam kategori tidak tercemar yang artinya air tersebut mempunyai kualitas yang baik. Hasil penelitian menunjukkan kualitas buah melon memiliki nilai rata-rata kadar air buah 95,19\%, kadar karbohidrat 1,99\%, kadar protein 1,37\%, kadar lemak 0,88\%, kadar abu 0,57\%, vitamin C 6,91\%, dan total padatan terlarut (kemanisan) 9,4 0brix. Kualitas melon tersebut tergolong pada kualitas rendah menurut SNI 7883-2013. Hasil kualitas air tanah dan kualitas buah melon tersebut menujukkan jika air tanah berpengaruh terhadap hasil kualitas dari tanaman melon.

Kata Kunci: Air tanah, Autopot, Fertigasi, Greenhouse dan Melon
\end{abstract}

\begin{abstract}
Hydroponic cultivation of melon plants with a fertigation system using ground water is one of the cultivation technologies that is expected to improve the quality and production of crops. Fertigation technology (fertilizer and irrigation) using autopot is an irrigation system allow to provide irrigation water by self-watering system by not using electric power so that the fertigation system is more efficient. The purpose of this study was to determine the effect of the impact of groundwater quality on the quality of melon (Cucumis melo L.) plants. The research method used is descriptive method. The quality parameters of the melon used in this study were water content, carbohydrate, protein, fat, ash, vitamin $C$ and sweetness (\% brix). The results of research on ground water quality show that the quality of ground water used is included in the category of non-polluted, which means that the water has good quality. The results showed the quality of melon has an average value of $95.19 \%$ fruit water content, $1.99 \%$ carbohydrate content, $1.37 \%$ protein content, 0.88\% fat content, $0.57 \%$ ash content, vitamin C $6,91 \%$, and total dissolved solids (sweetness) 9.4 Obrix. The quality of the melon is classified as low quality according to SNI 7883-2013. The results of the ground water quality and the quality of the melon shows if the ground water affects the quality of the melon plants.
\end{abstract}

Keywords: Groundwater, Autopot, Fertigation, Greenhouse and Melon.

How to Cite: Setiawati. R (2020). Dampak Kualitas Air Tanah Terhadap Kualitas Melon (Cucumis Melo L.). 
Agrotekma: Jurnal Agroteknologi dan Ilmu Pertanian. 4 (2): 83-93 


\section{PENDAHULUAN}

Pertumbuhan penduduk di dunia yang semakin meningkat akan berpengaruh terhadap permintaan bahan pangan, maka dari itu diperlukan peningkatan hasil produksi pertanian. Komoditas hortikultura merupakan salah satu sumber pertumbuhan di dalam sektor pertanian, karena produk-produk hortikultura memiliki pangsa pasar yang tinggi. Buah-buahan adalah salah satu kelompok komoditas hortikultura yang memiliki permintaan domestik cukup tinggi karena memiliki peranan penting dalam hal pemenuhan gizi masyarakat dan potensi ekonomi (Harjadi, 1989). Hal ini ditandai dengan banyaknya pasokan buahbuahan impor yang beredar di pasaran. Buah juga merupakan sumber penting dalam dalam pemenuhan kebutuhan vitamin yang diperlukan oileh tubuh. Kandungan vitamin dan mineral diperlukan untuk memenuhi kebutuhan energi serta mencegah berbagai macam penyakit.

Melon adalah salah satu jenis buah yang memiliki kandungan vitamin dan mineral. Melon ini merupakan jenis tanaman semusim dan memiliki nilai jual yang tinggi. Adanya perubahan iklim global menjadi salah satu kendala turunnya produktivitas dan kualitas hasil panen. Maka dari itu diperlukan alternatif teknologi budidadaya yang dapat meningkatkan mutu dan produksi hasil panen buah melon, salah satu caranya adalah dengan budidaya secara hidroponik. Budidaya secara hidroponik bisa dilakukan di lahan yang minim, sehingga ini dapat dijadikan suatu hobi maupun bisnis yang cukup menggiurkan. Berbagai jenis tanaman bisa dibudidayakan dengan cara hidroponik, baik itu tanaman hias, sayur, buah dan tanaman obat-obatan. Akan tetapi ada beberapa perlakuan yang harus diperhatikan dalam budidaya secara hidroponik, seperti kualitas air dan nutrisi tanaman.

Pemberian air irigasi pada hakikatnya menjadi salah satu hal penting dalam pertumbuhan dan perkembangan tanaman. Pemberian air irigasi yang tidak tepat sangat mempengaruhi hasil panen dan kualitas buah (Anas dkk, 2013). Pemberian air irigasi dalam budidaya hidropinik dapat menggunakan air tanah. Pada umumnya air tanah terdapat dalam lapisan tanah baik dari yang dekat dengan permukaan tanah sampai dengan yang jauh dari permukaan tanah.

Kualitas air yang diinginkan oleh tanaman hidroponik yaitu air dengan kadar mineral terlarut 0-50 ppm (Fah, 
1986). Semakin rendahnya kadar mineral terlarut di dalam air akan membuat kualitas air itu semakin baik untuk tumbuhnya tanaman hidroponik. Kebanyakan tanaman hidroponik menginginkan nilai pH optimal antara 5.57.5 (Lingga, 1999). Kriteria air irigasi tanaman harus memenuhi persyaratan parameter fisika daya hantar listrik (EC) sebesar 0,275-1,8 mS/cm; residu terlarut atau TDS sebanyak 200-1000 mg/l; residu tersuspensi atau TSS sebanyak 100-500 $\mathrm{mg} / \mathrm{l}$; dan parameter kimiawi anorganik yaitu pH sebesar 6,5-8 (Iskandar, 2014).

Nilai pH dibawah angka 5 akan cenderung bersifat asam yang akan mengakibatkan rusaknya sel-sel akar tanaman, dan nilai $\mathrm{pH}$ yang ada di atas angka 7,5 akan cenderung memiliki sifat basa serta meracuni tanaman (Mas'ud, 2009). Maka dari itu tidak semua jenis air bisa menjadi media tumbuh untuk tanaman hidroponik, seperti air laut (tinggi nilai garamnya, bersifat asam).

Penelitian ini ditujukan untuk Mengetahui kualitas air yang digunakan sebagai air irigasi pada sistem fertigasi menggunakan autopot dengan parameter uji meliputi pH, EC/DHL, kekeruhan/warna, TDS (total padatan terlarut) dan TSS (total padatan tersuspensi). Kemudina mengkaji kualitas hasil panen buah melon mencakup kadar air, karbohidrat, protein, lemak, abu, vitamin $\mathrm{C}$ dan kemanisan (\% brix).

\section{METODE PENELITIAN}

Metode yang digunakan pada penelitian ini menggunakan metode deskriptif yaitu, melakukan pengukuran, pengamatan, perhitungan dan analisis data secara kuantitatif. Metode deskriptif ini akan menggambarkan hubungan kualitas air tanah terhadap kualitas buah dan produktivitas dari buah melon. Penelitian ini dilakukan dengan menguji kualitas air yang digunakan sebagai air irigasi pada sistem hidroponik menggunakan autopot. Pengujian kualitas air dilakukan di Laboratorium Ekologi Universitas Padjajaran. Parameter yang di uji meliputi, TDS, TSS, EC, pH, kekeruhan dan EC/DHL. Penelitian ini juga dilakukan pengujian terhadap kulitas buah melon dengan parameter yang diuji kadar air, karbohidrat, protein, lemak, abu, vitamin $\mathrm{C}$ dan kemanisan (\%brix).

Pengambilan sampel air dilakukan pada sumur gali penduduk di Kelurahan Cibeureum. Metode pengambilan sampel dilakukan dengan pengambilan sampel sesaat (grab sample). Yaitu metode pengambilan sampel dengan cara sampel diambil langsung dari badan air yang sedang dipantau. Penelitian ini dilakukan dengan mengambil sampel sebanyak 3 kali ulangan agar didapatkan data yang lebih 
akurat. Prosedur pengambilan sampel berdasarkan SNI 06-2412-1991.

\section{Pengujian Kualitas Air}

Analisis yang dilakukan untuk mendapatkan data kualitas air adalah dengan menganalisis dan membandingkan data yang didapatkan dari hasil pengujian kualitas air di laboratorium dengan kriteria air irigasi sesuai dengan pedoman mengenai Kriteria Mutu Air (KMA) yang berasal dari FAO, BMKG, dan literaturliteratur terkait. Data yang dianalisis merupakan nilai dari parameter pH, TDS, TSS, EC/DHL dan kekeruhan. Analisis dilanjutkan dengan mendeskripsikan datadata yang diperoleh serta kaitannya dengan kriteria kebutuhan irigasi tanaman melon. Tabel 1 merupakan beberapa parameter untuk menguji kualitas air.

\begin{tabular}{cccc}
\multicolumn{4}{c}{ Tabel 1. Parameter Uji Kualitas Air } \\
\hline No & Parameter & Satuan & Keterangan \\
\hline 1 & $\mathrm{pH}$ & - & In Site \\
2 & $\mathrm{TSS}$ & $\mathrm{mg} / \mathrm{l}$ & Uji \\
& & & Laboratorium \\
3 & $\mathrm{TDS}$ & $\mathrm{mg} / \mathrm{l}$ & Uji \\
Laboratorium \\
4 & EC/DHL & - & In Site \\
5 & Kekeruhan & $\mathrm{mg} / \mathrm{l}$ & Uji \\
\end{tabular}

\section{Pengujian Kualitas Buah Melon}

Pengujian kualitas buah melon meliputi: Pengamatan kualitas hasil panen buah melon dilakukan dengan menimbang hasil produksi panen buah melon dan melakukan pengujian kualitas buah. Parameter yang dianalisis diantaranya kadar air, kadar lemak, kadar protein, kadar abu, kadar karbohidrat, kadar vitamin $\mathrm{C}$, dan total padatan terlarut atau kemanisan (\%brix). Kualitas buah melon yang dilakukan pengujian di Laboratorium Jasa Uji Teknologi Pangan Fakultas Teknologi Industri Pertanian dengan metode pengukuran sebagai berikut:

Tabel 2. Parameter Uji Kualitas Buah Melon

\begin{tabular}{cll}
\hline No. & \multicolumn{1}{c}{ Parameter } & \multicolumn{1}{c}{$\begin{array}{c}\text { Metode } \\
\text { Pengukuran }\end{array}$} \\
\hline 1. & Kadar air & Gravimetri \\
2. & Lemak & Soxlet \\
3. & Protein & Kjeldal \\
4. & Mineral & Gravimetri \\
5. & Karbohidrat & By different \\
6. & Vitamin C & Iodimetri \\
7. & Total Padatan Terlarut/ & Uji \\
\%brix \\
\hline
\end{tabular}

\section{HASIL DAN PEMBAHASAN}

A. Kualitas Air Tanah

Pengambilan sampel air tanah dilakukan 3 kali pengulangan. Pengambilan sampel dilakukan pada pagi hari dengan selang waktu satu minggu untuk 1 kali ulangan. Pengulangan pada pengambilan sampel air dilakukan untuk mewakili variasi data yang mungkin didapatkan di lapangan serta digunakan untuk perhitungan data secara statistik. Sampel yang telah diperoleh, selanjutnya diuji di Laboratorium Ekologi Universitas Padjajaran dan di uji secara in situ. Parameter yang diuji di laboratorium 
adalah TSS dan warna. Parameter suhu dan pH di uji secara in situ.

Hasil pengujian kualitas air tanah disajikan pada Tabel 3 sebagai berikut.

Tabel 3. Hasil Pengujian Kualitas Air Tanah

Tabel 3. Hasil Pengujian Kualitas Air Tanah

\begin{tabular}{clcc}
\hline No. & Parameter & Satuan & $\begin{array}{c}\text { Hasil analisa } \\
\text { sampel }\end{array}$ \\
\hline 1. & TSS & & \\
2. & TDS & $\mathrm{mg} / \mathrm{L}$ & 3,2 \\
3. & DHL/EC & $\mathrm{mg} / \mathrm{L}$ & 15,2 \\
4. & $\mathrm{pH}$ & - & 0,75 \\
5. & Kekeruhan & $\mathrm{NTU}$ & 7,0 \\
\hline
\end{tabular}

TSS (Total Suspended Solids) atau total padatan tersuspensi merupakan indikator fisika kualitas air berupa bahanbahan atau residu tersuspensi yang tertahan pada kertas saring, baik bahan anorganik maupun bahan organik yang melayang-layang dalam air (Effendi, 2003). Hasil pengujian kadar TSS air sebesar 3,2 $\mathrm{mg} / \mathrm{L}$, berdasarkan nilai tersebut maka termasuk ke dalam kriteria sangat baik karena memiliki kadar residu tersuspensi yang relatif sangat kecil. Guidelines for Interpretation of Water Quality for Irigation (FAO, 1985) menentukan kriteria kebutuhan air irigasi tanaman harus memenuhi persyaratan residu tersuspensi < $100 \mathrm{mg} / \mathrm{L}$ untuk kriteria air irigasi sangat baik dan < $500 \mathrm{mg} / \mathrm{L}$ untuk kriteria air irigasi baik.
TDS (Total Dissolved Solids) atau total padatan terlarut merupakan bahanbahan terlarut berupa senyawa-senyawa kimia dan bahan-bahan lain yang tidak tersaring pada kertas saring. TDS berupa residu yang masih tercampur dalam larutan disebabkan oleh bahan anorganik berupa ion-ion dari garam yang terdapat dalam air (Effendi, 2003). Berdasarkan pernyataan tersebut, maka TDS erat kaitannya dengan EC. Semakin besar TDS, semakin besar nilai EC. Hasil pengukuran nilai TDS yang terkandung dalam air sebesar 15,2 mg/L, maka air ini termasuk ke dalam kategori sangat baik. Berdasarkan Corolado Irrigation Water dalam Alberta Environment (2000), air yang digunakan untuk irigasi yang memiliki kandungan TDS < $200 \mathrm{mg} / \mathrm{L}$ termasuk kriteria air irigasi sangat baik dan $<1.000 \mathrm{mg} / \mathrm{L}$ untuk kriteria air irigasi baik.

Besar atau kecilnya nilai DHL/EC bergantung kepada banyaknya ion-ion anorganik serta konsentrasi larutan tersebut, sehinga menunjukkan salinitas suatu larutan, semakin banyak garamgaram terlarut yang dapat terionisasi dalam air, semakin tinggi pula nilai EC (Effendi, 2003).

Berdasarkan FAO (1976), air yang digunakan untuk irigasi memiliki nilai EC < $750 \mu \mathrm{mhos} / \mathrm{cm}$ atau setara dengan $<0,75$. 
Berdasarkan Corolado Irrigation Water dalam Alberta Environment (2000), air yang digunakan untuk irigasi sebaiknya memiliki nilai EC $<250 \mu \mathrm{mhos} / \mathrm{cm}$ atau setara dengan $<0,25 \mathrm{mS} / \mathrm{cm}$ untuk kriteria sangat baik dan 250-750 $\mu \mathrm{mhos} / \mathrm{cm}$ atau setara dengan 0,25-0,75 mS/cm. Nilai EC yang terdapat pada sampel air sebesar $0,75 \mathrm{mS} / \mathrm{cm}$ sudah sesuai dengan kriteria air irigasi.

Kadar pH merupakan salah satu parameter kimiawi yang menyatakan keasaman atau kebasaan suatu larutan. $\mathrm{pH}$ terdiri dari unsur hidrogen yang merupakan unsur pembuat asam. Berdasarkan Tabel 4 menunjukkan bahwa pH air tersebut adalah normal karena memiliki nilai 7. Nilai pH tersebut memiliki kadar yang sesuai dengan kriteria irigasi FAO (1985) yaitu memiliki pH 6,5-8.

Kekeruhan atau turbiditas merupakan derajat kegelapan dalam air yang disebabkan oleh residu-residu yang melayang di dalam air. Kekeruhan disebabkan oleh adanya bahan organik dan anorganik berupa plankton maupun organisme lain (Effendi, 2003). Nilai kekeruhan air sebesar 4,78 NTU. Kadar kekeruhan erat kaitannya dengan kadar zat tersuspensi atau TSS, keruhnya air tanah ini disebabkan oleh zat-zat tersuspensi dalam air tersebut yang akan menghalangi cahaya menembus air, sehingga ketika kandungan TSS meningkat maka kekeruhan air pun akan meningkat, maka dari itu air yang sesuai dengan kriteria irigasi adalah air yang tidak melebihi kadar maksimum TSS sehingga air masih tidak terlalu keruh.

\section{B. Kualitas Buah Melon}

Kualitas buah melon dapat dikategorikan baik apabila memenuhi persyaratan parameter utama seperti bobot, kondisi fisik, dan kandungan yang terdapat dalam buah khususnya kadar air, total padatan terlarut atau kadar kemanisan (\% brix) dan vitamin C. Analisis kualitas hasil panen buah melon yang dilakukan adalah analisis bobot, uji proksimat, kadar kemanisan dan vitamin C.

Sampel yang diuji sebanyak 2 buah, yang memiliki bobot 746 gram dan 710,5 gram. Berdasarkan SNI 7783-2013, melon yang diuji tersebut memiliki bobot kurang dari 1,5 kilogram sehingga dikategorikan ke dalam melon berkode ukuran 4 (BSN, 2013). Setiap bobot melon yang berbeda tentu memiliki kandungan buah yang berbeda. Kandungan gizi buah melon terdapat pada Tabel 4.

Tabel 4. Kandungan Gizi Buah Melon

\begin{tabular}{llcl} 
No. & $\begin{array}{l}\text { Parameter } \\
\text { Pengujian }\end{array}$ & $\begin{array}{c}\text { Satuan } \\
\text { Hasil }\end{array}$ & $\begin{array}{c}\text { Hasil Analisa } \\
\text { Sampel Buah }\end{array}$ \\
\hline
\end{tabular}




\begin{tabular}{llcc}
\hline 1. & Air & $\%$ & 95,19 \\
2. & Lemak & $\%$ & 0,88 \\
3. & Abu & $\%$ & 0,57 \\
4. & Protein & $\%$ & 1,37 \\
5. & Karbohidrat & $\%$ & 1,99 \\
6. & Vitamin C & $\%$ & 6,91 \\
7. & Kemanisan & ${ }^{0}$ Brix & 9,4 \\
\hline
\end{tabular}

\section{Analisis Proksimat}

Berdasarkan Tabel 4 menunjukkan bahwa kadar air yang didapatkan pada sampel buah melon sebesar 95,19\%. Buah melon yang berkualitas baik memiliki kandungan kadar air sebanyak 93\% (Tjahjadi, 1987), hal ini menunjukkan bahwa kandungan kadar air yang dimiliki oleh sampel buah melon pada penelitian ini memenuhi persyaratan melon berkualitas baik karena masih mendekati persyaratan parameter kadar air 93\%. Kadar air berkaitan erat dengan kesegaran, semakin banyak kadar air yang terkandung dalam buah maka daging buah akan semakin legit dan segar ketika dikonsumsi, namun buah yang segar belum tentu memiliki kandungan gizi yang optimal. Buah yang memiliki kadar air lebih dari 95\% akan mudah busuk dan mudah pecah apabila disimpan terlalu lama serta terasa sangat lembek apabila dikonsumsi (Ryall dkk., 1982).

Buah melon merupakan buah yang tergolong memiliki kadar lemak sangat rendah. Kadar lemak yang terdapat pada sampel penelitian ini adalah 0,88\%. Umumnya kandungan lemak atau total fat pada 100 gram buah melon adalah sebanyak 0,19\% (Sobir dan Siregar, 2010). Kadar abu menunjukkan berbagai mineral yang terkandung dalam suatu bahan. Kadar abu atau mineral yang terkandung dalam sampel buah melon adalah 0,57\%. Berdasarkan hasil tersebut, kadar abu dari sampel tersebut termasuk ke dalam kualitas melon baik karena melon yang baik memenuhi kandungan kadar abu sebanyak 0,4\% (Tjahjadi, 1987). Penentuan kadar abu berhubungan erat dengan kandungan mineral yang ada dalam suatu bahan, kemurnian, serta kebersihan suatu bahan yang dihasilkan. Pengukuran kadar abu bertujuan untuk mengetahui besarnya kandungan mineral yang terdapat dalam suatu bahan pangan (PERSAGI 2009).

Kandungan protein pada sampel buah melon penelitian ini memiliki kandungan 1,37\%. Kandungan protein dari kedua perlakuan fertigasi interval tersebut masih memenuhi persyaratan buah melon dengan kualitas baik yaitu memiliki kandungan protein sebanyak 0,6\% (Tjahjadi, 1987).

Menurut Tjahjadi (1987), buah melon yang berkualitas baik memiliki kandungan karbohidrat $6 \%$, namun pada penelitian ini hasil pengujian yang diperoleh kurang dari $6 \%$, yaitu sebesar 1,99\%. Kandungan karbohidrat pada buah akan berpengaruh 
terhadap kemanisan buah karena karbohidrat merupakan glukosa (sakarida), nilai karbohidrat yang rendah akan menyebabkan kemanisan pada buah rendah.

\section{Kadar Vitamin C}

Vitamin C pada sampel buah melon penelitian ini memiliki kandungan sebanyak 6,91\%. Kandungan vitamin C yang dimiliki oleh buah melon berkualitas baik adalah 30\% (Prajnanta, 2004).

Kandungan vitamin C yang rendah dapat disebabkan karena kondisi sampel ketika sudah dibelah tidak langsung dilakukan pengujian vitamin $C$, vitamin $C$ merupakan vitamin yang paling tidak stabil dari semua jenis vitamin sehingga mudah mengalami kerusakan dan perubahan kadar selama proses penyimpanan karena dipengaruhi oleh adanya oksigen dan paparan cahaya yang akan merusak asam askorbat pada buah melon, dalam hal ini adalah vitamin C. Proses reduksi dan oksidasi mempengaruhi penurunan kadar vitamin C karena vitamin ini sangat mudah teroksidasi. Faktor lain yang dapat mempengaruhi kehilangan kandungan vitamin C pada buah yaitu kerusakan karena benturan dan luka beku atau chilling injury (Parviainen, 1992). Kandungan vitamin $\mathrm{C}$ juga sangat dipengaruhi oleh varietas, kondisi lingkungan tempat tumbuh, jenis pupuk yang digunakan, dan tingkat kematangan buah.

\section{Kadar Total Padatan Terlarut/Kemanisan (Indeks Brix)}

Indikator tingkat kemanisan ditentukan dari nilai Total Padatan Terlarut (TPT) yang dinyatakan dalam \% brix (Rubatzky dan Yamaguchi, 1999). Nilai TPT berdasarkan pengujian kemanisan buah melon sebesar 9,4 0Brix.

Menurut SNI 7883-2013 persyaratan mutu buah melon yang harus dipenuhi adalah memiliki padatan terlarut total daging buah (brix) minimum 10\% (BSN, 2013). Derajat brix atau kandungan TPT untuk menyatakan kualitas buah melon dikatakan rendah apabila memiliki nilai di bawah $8 \%$, rata-rata sebesar $10 \%$, baik sebesar $12 \%$, dan bermutu apabila mencapai 14\% (Tjahjadi, 1987).

Nilai TPT berdasarkan pengujian kemanisan buah melon sebesar 9,4 0Brix menunjukkan bahwa nilai rata-rata TPT hampir memenuhi persyaratan mutu ratarata buah melon. Kemanisan buah erat kaitannya dengan karbohidrat karena secara kimiawi karbohidrat sama dengan gula atau bisa diartikan sebagai karbohidrat yang memiliki rasa manis. Rasa manis yang biasa terdapat pada tanaman terutama disebabkan oleh tiga 
jenis gula yaitu sakarosa, fruktosa dan glukosa. Nilai karbohidrat yang rendah pada hasil buah panen ini berbanding lurus dengan nilai TPT.

Menurut Santoso (2011), melon yang kadar kemanisannnya masih rendah adalah melon yang belum matang karena kandungan karbohidratnya belum pecah menjadi sakarida, melainkan masih berbentuk pati (polisakarida). Proses pemecahan senyawa karbohidrat ini terjadi secara enzimatis dengan bantuan enzim fosforilase, glukoamilase dan amilase. Bertambahnya kadar TPT juga terjadi karena laju respirasi terus meningkat hingga terbentuk sukrosa, glukosa, dan fruktosa yang membuat buah akan menjadi semakin manis. Berdasarkan pernyataan tersebut, faktor yang mempengaruhi kadar kemanisan yang rendah adalah kondisi melon yang sudah tidak optimal ketika masih dalam masa pematangan buah, yang menyebabkan proses pemecahan karbohidrat menjadi sukrosa dan glukosa dan fruktosa tidak sempurna, sehingga buah memiliki kadar TPT yang rendah. Kondisi kerusakan melon tersebut dapat disebabkan karena suhu lingkungan yang melebihi suhu optimum sehingga kemampuan tanaman dalam menyerap larutan hara semakin berkurang sehingga proses pematangan buah menjadi terhambat. Suhu yang terlalu tinggi juga dapat menyebabkan bakal buah menguning sehingga perkembangan buah menjadi kurang baik kualitasnya.

\section{Hubungan Kualitas Air dengan Kualitas Hasil Panen Buah Melon}

Hasil pengujian kualitas air tanah yang digunakan sebagai sumber air fertigasi di Greenhouse (Tabel 5) menunjukkan bahwa kelima parameter sudah memenuhi kriteria irigasi yang ditentukan oleh FAO (1985), akan tetapi belum sesuai dengan kebutuhan tanaman melon terutama pada parameter pH, EC, dan TDS. Nilai pH dipengaruhi oleh reaksi reduksi dan oksidasi yang terjadi selama penyaluran air, sedangkan nilai EC dan TDS menunjukkan nilai salinitas atau zat garam yang terdapat pada air hujan.

Huang dkk. (2012) menyatakan bahwa nilai EC sangat berpengaruh terhadap kualitas hasil panen buah melon. Nilai EC berkaitan dengan TDS, semakin tinggi EC semakin tinggi juga TDS karena kadar zat garam yang ditunjukkan pada nilai EC akan menambah nilai zat padat terlarut (TDS) yang terdapat di dalam air. Zat garam juga akan menambah nilai zat padat tersuspensi (TSS) akibat adanya partikel-partikel zat garam yang mengendap atau tersuspensi pada air.

Air tanah yang digunakan pada sistem fertigasi autopot di Greenhouse sudah baik kualitasnya untuk memenuhi 
kebutuhan irigasi tanaman, akan tetapi harus disesuaikan dengan kebutuhan tanaman melon terutama pada parameter pH, EC, dan TDS. Tanaman juga memerlukan unsur hara makro dan mikro agar tumbuh dengan optimal dan menghasilkan kualitas buah yang baik, karena tanaman melon ditanam pada media tanam bukan tanah sehingga media belum memiliki unsur hara yang diperlukan untuk tanaman. Penambahan zat garam seperti nitrat, fosfat, dan kalium sangat diperlukan untuk menambah kadar EC dan menurunkan kadar pH pada air irigasi tanaman.

Sumber air fertigasi dari air tanah ini menghasilkan kualitas buah melon dengan kadar kemanisan yang relatif rendah (Tabel 6) menunjukkan bahwa kualitas hasil panen buah melon tergolong dalam melon berkualitas rendah karena belum memenuhi persyaratan mutu buah melon merujuk pada SNI 7883-2013.

\section{SIMPULAN}

Hasil penelitian memiliki nilai ratarata kadar air buah 95,19\%, kadar karbohidrat 1,99\%, kadar protein 1,37\%, kadar lemak 0,88\%, kadar abu 0,57\%, vitamin C 6,91\%, dan total padatan terlarut (kemanisan) 4,43\%brix. Kualitas melon tersebut tergolong pada kualitas rendah menurut SNI 7883-2013.

Hasil penelitian menunjukkan bahwa kualitas hasil panen buah melon pada penelitian ini tidak sepenuhnya dipengaruhi oleh kualitas air tanah, melainkan dipengaruhi oleh kondisi salinitas dari zat garam pada air yang diberikan dan kondisi iklim selama masa tanam melon. Kondisi iklim yang terlalu tinggi akan menyebabkan tanaman tidak optimal dalam menyerap unsur hara yang dibutuhkan sebelum masa pematangan buah berakhir, sehingga total padatan terlarut (kemanisan) pada buah menjadi rendah dan menurunkan kualitas buah melon tersebut.

\section{UCAPAN TERIMAKASIH}

Dalam pelaksanaan dan pembuatan paper ini penulis menghadapi beberapa masalah. Namun, berkat dukungan dari beberapa pihak akhirnya penulis dapat menyelesaikan laporan Penelitian ini. Pada kesempatan ini penulis mengucapkan terima kasih kepada Prof. Dr. Ir. $\mathrm{Hj}$. Nurpilihan Bafdal, M.Sc selaku ketua komisi pembimbing yang telah memberikan arahan, penjelasan dan ilmu yang bermanfaat bagi penulis serta telah mendanai penelitian ini. Semoga paper ini dapat memberikan pengetahuan bagi pembacanya dan bermanfaat bagi yang 
berkepentingan, khususnya bagi penulis

sendiri.

\section{DAFTAR PUSTAKA}

Anas D. Susila \& Roedhy Poerwanto, 2013. Peran Manajemen Budidaya Tanaman.Fakultas Pertanian. Insititut Pertanian Bogor. Bogor.

Chay Asdak, 2007. Hidrologi dan Pengelolaan Daerah Aliran Sungai. Yogyakarta: Gadjah Mada University Press.

Effendi, H. 2003. Telaah Kualitas Air Bagi Pengelolaan Sumber Daya dan Lingkungan Perairan. Yogyakarta. Kanisius.

Fah, J. 1986. Hydroponics Made Easy A Useful Guide for Novice and Intermediate Users of Hydroponics. Bayswater, Vic : Agromatic Corporation Pty Ltd. Vol. 2. Bogor.

Harjadi, S. S. 1989. Dasar - dasar Hortikultura. Departemen Budidaya Pertanian. Fakultas Pertanian. Institut Pertanian Bogor. Bogor.

Huang, C.H., Zong, L., Buonanno, M., Xue, X., Wang, T., dan Tedeschi A. 2012. Impact of Saline Water Irrigation on Yield and Quality of Melon (Cucumis melo cv. Huanghemi) in Northwest China. Europe J. Agronomy 43 (2012) pg.68-76

Lingga, P. 1999. Hidroponik Bercocok Tanam Tanpa Tanah. Penebar Swadaya, Jakarta.

Mas'ud, H. 2009. Sistem Hidroponik dengan Nutrisi dan Media Tanam Terhadap Pertumbuhhan dan Hasil Selada. Media Penelitian dan Pengembangan Sulawesi Tengah 2 (2).

Parviainen, M.T., Nyyssonen, K., 1992. Ascorbic acid. In: Leenheer, A.P.D., Lambert, W.E., Nelis, H. (Eds.), Modern Chromatographic Analysis of Vitamins. Marcel Dekker, New York.

PERSAGI. 2009. Kamus Gizi Pelengkap Kesehatan Keluarga. Jakarta (ID): PT Kompas Media Nusantara.

Ryall, A.L dan Pentzer W.T. 1982. Handling, Transportation and Storage of Fruits and Vegetables. Second Edition. Volume 2. Westport, Connecticut. The Avi Publishing Company, Inc.

Rubatzky, V.E. dan M. Yamaguchi. 1999. Sayuran Dunia 3: Prinsip, Produksi, dan Gizi (diterjemahkan dari: World Vegetables: Principles, Production, and Nutritive Value, Second Edition. Penerjemah: C. Herison). Penerbit ITB. Bandung. 320 hal.

SNI. 1991. Metode Pengambilan Contoh Kualitas Air. SNI 06-2412-1991. Jakarta.

SNI. 2013. Melon. SNI 7883-2013. Jakarta

Santoso, B.B. 2011. Fisiologi dan Biokimia pada Komoditi Panenan Hortikultura. Buku Ajar
Fakultas Pertanian, Universitas Mataram, Mataram, Indonesia.

Sobir, dan Firmansyah, D, Siregar. 2010. Budidaya Melon Unggul. Penebar Swadaya. Jakarta.

Tjahjadi, N. 1994. Bertanam Melon. Kanisius Hal. 48. Jogjakarta.

Tjahjadi, N. 1987. Bertanam Melon, Yogyakarta: Kanisus

Yusuf, Iskandar, A. 2014. Kajian Kriteria Mutu Air Irigasi. Puslitbang SDA Kementrian PU. Jurnal Irigasi Volume 9 No.1. Jakarta. 